\title{
The Ethnobotany Study on the process of Kawa Beverage Processing (Coffea arabica L) in Kerinci District as a Media of Biology Applied Learning
}

\author{
Toni Haryanto ${ }^{1}$ \\ \{toni13stain@gmail.com ${ }^{1}$ \}
}

\begin{abstract}
Student of Doctoral Programof Mathematics and Science Education, Universitas Jambi Lecturer of Biology Department, Faculty of Education and Teacher Training of IAIN Kerinci ${ }^{1}$
\end{abstract}

\begin{abstract}
Kawa beverage is a traditional Kerinci drinkingwho made from dried coffee leaves. Kerinci has the potential of 1,789 hectares of Arabica coffee garden area. The purposed of this study was to reconstruct the original knowledge of the community in the process of processing the kawa beverage into scientific knowledge which was used as a media for biology applied learning. The Location of this research was in Ujung Pasir Village,Lake of Kerinci, Regency of Kerinci, Jambi Province. The method of this research was used phenomenology method with descriptive qualitative approach. The Data were collected by observation, interviews and documentation. The data obtained wasanalyzed by describing, inventorying, classifying and then constructing original knowledge and scientific knowledge into the concept of biology applied learning. The results of this research showed that the process of processing the beverage was approved out in the traditional way of hereditary knowledge who consisted of drying, burning, packaging, mixing and services. And all of the kawa beverage manufacturers do not use other excitement in mixing which have tastelessness and bitter, theservices is done by brewing. The process that has been interpreted into the concept of science can be implemented in the biology applied learning.
\end{abstract}

Keywords: Ethnobotany, Kawa Beverage (Coffea arabica L), Biology Applied Learning

\section{Introduction}

The application of biological science will certainly provide many benefits for human life, especially to improve welfare and produce goods or services for the benefit of humans. Many aspects of life can be used as applied biology studies such as aspects of agriculture, animal husbandry, medicine, industry, processing of natural resources, food, and so on. Understanding the community about the surrounding environment about the culture of hereditary knowledge needs to be introduced to the modern generation by applying it in the learning of applied biology.

Understanding of the use of plants in daily needs and ethnic customs for cultural interests is called ethnobotany. Ethnobotany is a multidisciplinary science that studies how interaction between humans and plants (Martin, 2010). Ethnobotany is a multidisciplinary science that studies how interactions between plants and human culture. Not limited to the use of plants for food, clothing and shelter but also includes their use for religious ceremonies, ornaments and health care (Meena and Meena, 2018). Research on ethnics that has been carried out about the 
salt production process which is the knowledge gained by the students can be analyzed from scientific concepts so that it can be a source of learning for students (Hadi and Ahied, 2017). Related to the research the benefits and usefulness of traditional herbal medicine concluded that many community science knowledge that can be transformed into scientific science and science learning resources for students (Sudarmin and Asyhar, 2012). In Kerinci is one area that is rich in culture, especially in the use of plants as daily necessities such as processing of coffee leaves into kawa beverage.

Kerinci Regency is an area located along the hill line and is in the most Western position of Jambi Province with an area of 420,000 Ha. Knowledge of laughing drinks in Kerinci is a nation's cultural heritage based on experiences that have been handed down from generation to generation. Kawa beverage (Coffea arabica L) is a traditionally processed beverage in Kerinci which is made from dried coffee leaf prunings. As we know, Kerinci has the potential of 1,789 hectares of Arabica coffee planting area spread in Kerinci Regency Jambi Province. One of the Kerinci people who believe in kawa drinks is the Ujung Pasir Village,Lake of Kerinci, Regency of Kerinci, Jambi Province. People in this area are more likely to use traditional drinks than modern drinks. It is believed that traditional drinks are more beneficial than modern drinks because they can provide vitality for the body. Community belief in the efficacy of kawa beverage is considered because of the presence of caffeine compounds which have efficacy as a central nervous system stimulant, because there are $0.17 \%$ caffeine of dried kawa leaves (Rasyid, Sanjaya and Zulharmita 2013). Positive coffee leaves contain caffeine by giving violet red color with Murexid reagent. The choice of this traditional drink is due to the temporary nature of the drink so that a person's dependence on the chemical content of the drink. In addition, the costs used by the community for traditional drinks are relatively cheaper compared to modern drinks so that many people switch to traditional drinks. Nearly $60 \%$ of the Ujung Pasir community still consumes kawa beverage. This culture still continues to this day. This knowledge will gradually disappear along with the development of modern technology. One of the factors causing the extinction of public knowledge about kawa beverage is the lack of interest in the older generation to express this knowledge in written form, while the younger generation today, especially those who have integrated with modern life, rarely care about the knowledge possessed by their people. Research conducted at Ujung Pasir only saw the tradition of kawa beverage as a reinforcement and an adhesive of kinship in communication facilities (Bahar, Defrianti and Fatonah, 2017).

The traditional process of making kawa beverage at Ujung Pasir, without realizing it, can actually be studied in relation to the science referred to as etnbotany. Ethnobotany is an attempt to reconstruct people's original knowledge into scientific knowledge. The processing kawa beverage must be learned from the natural sciences that underlie the processing process, namely the study of biology and chemistry. For this reason, there must be a special study that can document and identify ethnobotany activities in the processing of kawa beverage so that it is expected to improve the ability of the kawa beverage processing. In addition, the results of the documentation and identification of ethnobotany activities can be a source of learning in applied biology.

The purpose of this research is to reconstruct the original knowledge of the community in the process of processing the kawa beverage into scientific knowledge which is used as a medium for learning applied biology. The processing of kawa beverage is expected to be a source of contextual learning for students. In addition, it is expected that incorporating local wisdom into applied biology learning can spur students to strive to become movers in an effort to improve the welfare of the surrounding community. 


\section{Material And Methods}

This research was conducted at Ujung Pasir in Lake Kerinci Subdistrict, Kerinci Regency, Jambi Province in 2018. The method used in this research is Phenomenology method with descriptive qualitative approach (Cresswel, 2018). Taking primary data collected through observation and interview techniques while secondary data with literature and document studies (Rusdi, 2018). The reconstruction process is focused on community activities in the manufacture of kawa beverage and is associated with applied biology. The data obtained in the analysis by describing, inventorying, classifying and then constructing original knowledge and scientific knowledge in the processing of kawa beverage into the concept of applied biology learning.

\section{Results And Discussion}

Based on the results of observations and interviews with the community in Ujung Pasir, it was obtained information that the processing of kawa beverage was still done traditionally from hereditary knowledge, then the reconstruct the original knowledge of the community in the process of processing the kawa beverage into scientific knowledge.

The paradigm of science education that considers ethnobotany as national identity and local cultural customs as a vehicle for science learning is being developed in several studies. Learning with ethnobotany is based on the recognition of community culture as part of local wisdom that needs to be applied. In developing countries applied ethnobotany is very much needed because of the interaction or close relationship between local communities and plants (Hamilton, 2003). Ethnobotany approach is a study of knowledge systems that study the relationship between human culture and the surrounding plant environment (Meita and Pande, 2013).

It is important to reconstruct people's original knowledge into scientific knowledge because indigenous knowledge is not yet scientifically conceptualized and textually and contextually formalized (Sudarmin, 2014). activities kawa beverage processing carried out by the community in Ujung Pasir, Kecamatan Danau Kerinci, Kerinci Regency have applied indigenous science knowledge, but have not been elaborated and conceptualized in scientific science. This research has reconstructed the original knowledge that already existed in the processing of kawa beverage into scientific knowledge. The results of ethnobotany reconstruction of kawa beverage processing in this study can contribute to enriching the science of biology and chemistry, so that there will be a tangible relationship between theory and facts in the field and can be used as a learning media for applied biology. 
Table 1. Results of reconstruct the original knowledge into Scientific Knowledge

\begin{tabular}{|c|c|c|c|}
\hline No. & Question & Original Knowledge & Scientific Knowledge \\
\hline 1. & What is Kawa? & $\begin{array}{l}\text { Kawa is a complement drink } \\
\text { called Ujung Pasir Kerinci "aye } \\
\text { kawo" }\end{array}$ & $\begin{array}{l}\text { Kawa (Coffea arabica } L) \text { is a drink } \\
\text { of coffee leaf pruning from the } \\
\text { Family Rubiaceae with taxon } \\
\text { levels: } \\
\text { Kingdom: Plantae } \\
\text { Division: Magnoliophyta } \\
\text { Sub Division: Spermatophyta } \\
\text { Class: Magnoliopsida } \\
\text { Sub Class: Asteridae } \\
\text { Order: Rubiales } \\
\text { Family: Rubiaceae } \\
\text { Genus: Coffea } \\
\text { Species: Coffea arabica L. } \\
\text { With a collection of chemical } \\
\text { compounds whose main part is } \\
\text { caffeine which can be made into a } \\
\text { drink. } \\
\text { Science Concept: } \\
\text { Compounds and taxonomies }\end{array}$ \\
\hline 2. & $\begin{array}{l}\text { What is the } \\
\text { motivation for } \\
\text { processing kawa } \\
\text { beverage? }\end{array}$ & $\begin{array}{l}\text { Maintain traditions, establish } \\
\text { friendship, recitation, } \\
\text { information, cohesiveness, } \\
\text { friendship, friendship and can } \\
\text { give your body the spirit and } \\
\text { freshness. }\end{array}$ & $\begin{array}{l}\text { The motivation for processing kawa } \\
\text { beverage is classified into six } \\
\text { categories, namely (a) preserving } \\
\text { the tradition of traditional drinks, } \\
\text { (b) establishing friendship, (c) } \\
\text { being a means of communication, } \\
\text { (d) a means of bonding kinship and } \\
\text { friendship, and (e) giving body } \\
\text { spirit and vitality. } \\
\text { Science Concept: } \\
\text { Energy and Vitality }\end{array}$ \\
\hline 3. & $\begin{array}{l}\text { What are the } \\
\text { benefits and side } \\
\text { effects felt from } \\
\text { kawa beverage? }\end{array}$ & $\begin{array}{l}\text { Kawa drinks provide freshness } \\
\text { and a variety of health for the } \\
\text { body such as eliminating } \\
\text { headaches, adding to other } \\
\text { appetite. There have been no } \\
\text { side effects during consuming } \\
\text { kawa beverage. }\end{array}$ & $\begin{array}{l}\text { Dry coffee leaves contain less } \\
\text { caffeine than tea and coffee, coffee } \\
\text { leaves contain many antioxidants, } \\
\text { and anti-inflammatory substances. } \\
\text { Coffee leaves have efficacy as a } \\
\text { central nervous system stimulant, } \\
\text { because in dry coffee leaves there is } \\
0.17 \% \text { caffeine. Due to the low } \\
\text { caffeine content, it does not give } \\
\text { side effects to health. } \\
\text { Science Concept: } \\
\text { Its compounds and functions }\end{array}$ \\
\hline 4. & $\begin{array}{l}\text { Where do you get } \\
\text { the knowledge of } \\
\text { making kawa } \\
\text { beverage? }\end{array}$ & $\begin{array}{l}\text { Derived from hereditary } \\
\text { ancestors, parents, and fellow } \\
\text { drink kawa drinkers . }\end{array}$ & $\begin{array}{l}\text { Heritage knowledge, conventional, } \\
\text { local wisdom, unformalized, and } \\
\text { underdeveloped like scientific } \\
\text { science. } \\
\text { Science Concept: } \\
\text { Local wisdom }\end{array}$ \\
\hline 5. & What kawa is & Local coffee leaves whose & The types of coffee are Robusta \\
\hline
\end{tabular}




\begin{tabular}{|c|c|c|c|}
\hline No. & Question & Original Knowledge & Scientific Knowledge \\
\hline & used? & $\begin{array}{l}\text { leaves are not serrated (do not } \\
\text { know the type name) }\end{array}$ & $\begin{array}{l}\text { (Coffea canephora var. Robusta) } \\
\text { has thin serrated leaves, Arabica } \\
\text { (Coffea arabica L) has fragrant } \\
\text { leaves that are concentrated green } \\
\text { and not jagged), Liberica (Coffea } \\
\text { liberica) has thick leaves with a } \\
\text { rough texture, and Excelsa (Coffea } \\
\text { excelsa) has smooth, thin and small } \\
\text { leaves. In Kerinci there is coffee } \\
\text { type arabica. } \\
\text { Science Concept: } \\
\text { Plant Classification }\end{array}$ \\
\hline 6. & $\begin{array}{l}\text { What is the raw } \\
\text { material for kawa } \\
\text { beverage? }\end{array}$ & $\begin{array}{l}\text { Coffee leaves obtained from the } \\
\text { garden. }\end{array}$ & $\begin{array}{l}\text { The types of plants found in Kerinci } \\
\text { which can be useful as drinks are } \\
\text { tubers (uber), roots (radix), stems } \\
\text { (ligna), leaves (folia), flowers } \\
\text { (fructus), seeds (cement), plants } \\
\text { (herbs), and so on. } \\
\text { Examples of each type of kawa } \\
\text { beverage are mentioned by the } \\
\text { respondent. } \\
\text { Science Concept: } \\
\text { Plant structure }\end{array}$ \\
\hline 7. & $\begin{array}{l}\text { What is the kawa } \\
\text { beverage } \\
\text { equipment? }\end{array}$ & $\begin{array}{l}\text { Clasps (from split bamboo at } \\
\text { the ends), firewood, shelves, } \\
\text { plastic, plastic bags, spoons, } \\
\text { pans / kettles and plastic bowls. }\end{array}$ & $\begin{array}{l}\text { The tools used are tongs, firewood, } \\
\text { shelves, plastic, plastic bags, } \\
\text { spoons, pots / pans and plastic } \\
\text { bowls. } \\
\text { Science Concept: } \\
\text { Ethnobotany }\end{array}$ \\
\hline 8. & $\begin{array}{l}\text { How is it the } \\
\text { process of } \\
\text { processing the } \\
\text { kawa beverage? }\end{array}$ & $\begin{array}{l}\text { Pure / fresh coffee leaves which } \\
\text { are pruned from the garden are } \\
\text { prepared and arranged in clasps } \\
\text { made of bamboo which are } \\
\text { divided at the edges, as much as } \\
4 \text { handheld, leaf compilation } \\
\text { starting from the younger ones } \\
\text { at the ends of clasps, then } \\
\text { placing them on a shelf that is } \\
1.5 \text { m away from the fire source } \\
\text { (kitchen) for } 6 \text { days for drying. } \\
\text { After that, it is burned / } \\
\text { accommodated by holding the } \\
\text { in clasps directly to the source } \\
\text { of the fire that uses firewood } \\
\text { from various types such as } \\
\text { mambu wood, cinnamon wood } \\
\text { and others by going back and } \\
\text { forth for } 20 \text { minutes until it is } \\
\text { black and dry / crispy, then } \\
\text { remove it from the clamp / } \\
\text { clamp then smash it and put it }\end{array}$ & $\begin{array}{l}\text { The stage of processing the kawa } \\
\text { beverage consists of: } \\
\text { (a) Drying / withering stage } \\
\text { Fresh coffee leaves that have } \\
\text { been selected and separated } \\
\text { from the old and young, the } \\
\text { preparation of leaves from the } \\
\text { younger ones on the clamp as } \\
\text { much as } 3 \mathrm{~kg} \text { then dried using } \\
\text { fumigation from a fire source in } \\
\text { the kitchen placed on a shelf } \\
\text { with a distance of } 1.5 \mathrm{~m} \text { from } \\
\text { the source of the fire so as not } \\
\text { to get too close and exposed to } \\
\text { smoke which is carried out for } 6 \\
\text { days. Separation of the old and } \\
\text { young leaves on the tongs is } \\
\text { done because the leaves are } \\
\text { easily flammable and dry so } \\
\text { they are easily controlled in the }\end{array}$ \\
\hline
\end{tabular}




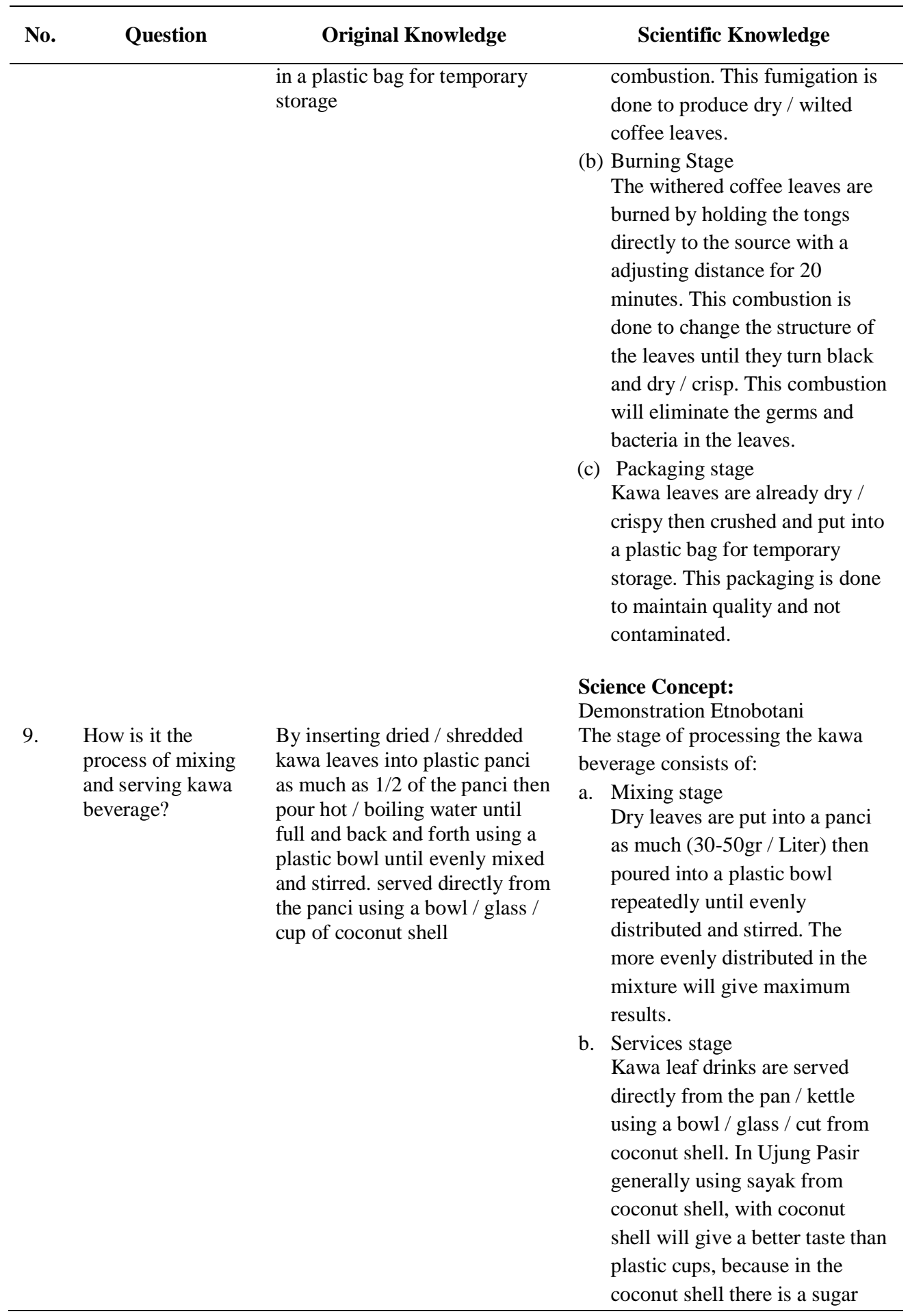




\begin{tabular}{|c|c|c|c|}
\hline No. & Question & Original Knowledge & Scientific Knowledge \\
\hline & & & $\begin{array}{l}\text { content such as cellulose and } \\
\text { hemicellulose. } \\
\text { Science Concept: } \\
\text { Solution and Nutrition }\end{array}$ \\
\hline 10. & $\begin{array}{l}\text { Are there } \\
\text { additional } \\
\text { ingredients in the } \\
\text { kawa beverage? }\end{array}$ & $\begin{array}{l}\text { There is only kawa and water } \\
\text { without additional ingredients, } \\
\text { which has two tastes, which are } \\
\text { tasteless and somewhat bitter }\end{array}$ & $\begin{array}{l}\text { All processors for kawa beverage at } \\
\text { Ujung Pasir do not provide } \\
\text { additional ingredients in brewing } \\
\text { drinks, people prefer the drink in } \\
\text { the original form and do not add to } \\
\text { other ingredients such as sugar, } \\
\text { milk and others. People prefer the } \\
\text { original taste as it is rather bitter } \\
\text { compared to tastes. With pure kawa } \\
\text { beverage without additional } \\
\text { ingredients it will certainly avoid } \\
\text { the risk of side effects on the drink. } \\
\text { Science Concept: } \\
\text { Nutrition }\end{array}$ \\
\hline 11. & $\begin{array}{l}\text { Are the kawa } \\
\text { beverage sold? }\end{array}$ & $\begin{array}{l}\text { Processing of kawa beverage } \\
\text { not for sale is only made for } \\
\text { personal needs and the } \\
\text { surrounding community. }\end{array}$ & $\begin{array}{l}\text { All processing for kawa beverage at } \\
\text { Ujung Pasir are not for sale but only } \\
\text { for individuals and communities } \\
\text { around them. People who come } \\
\text { home sometimes contribute to the } \\
\text { provision of coffee leaves and wood } \\
\text { for burning. } \\
\text { Science Concept: } \\
\text { Etnobotani }\end{array}$ \\
\hline
\end{tabular}

From table 1 it can be seen that the processing of kawa beverage in Ujung Pasir can be associated with basic competencies in learning in higher education, where students understand applied biology as a science and its relation to other sciences and can apply understanding of concepts and principles of applied biology in general in education in the community

Table 2. The Relationship Between kawa Beverage Processing Process and Basic Competences of Applied Biology Learning

\begin{tabular}{lll}
\hline No. & \multicolumn{1}{c}{ Competency standards } & Scientific Concept in Kawa Beverage Processing \\
\hline $1 . \quad \begin{array}{l}\text { Explaining the types of coffee leaves } \\
\text { used in processing kawa beverage. }\end{array}$ & $\begin{array}{l}\text { The names of the types of coffee and one of them is } \\
\text { arabica coffee. Arabica coffee (Coffea arabica L) is a } \\
\text { type of coffee that is abundant in Kerinci District } \\
\text { with the characteristics of fragrant leaves, thick } \\
\text { green, and not jagged. Dry coffee leaves contain } \\
\text { caffeine compounds of 0.17\%. }\end{array}$ \\
2. & $\begin{array}{l}\text { Explaining the concept of work in } \\
\text { the processing of kawa beverage and } \\
\text { their application in everyday life. }\end{array}$ & $\begin{array}{l}\text { preparation of drying, burning, mixing, packaging } \\
\text { until the presentation has been arranged according to } \\
\text { the time required at each stage. }\end{array}$ \\
\hline
\end{tabular}




\begin{tabular}{|c|c|c|}
\hline 3. & $\begin{array}{l}\text { Explaining the concept of chemistry } \\
\text { in kawa beverage and their } \\
\text { application in everyday life. }\end{array}$ & $\begin{array}{l}\text { The names of the compounds contained in the kawa } \\
\text { beverage one of are caffeine. } \\
\text { Compounds process for body health. }\end{array}$ \\
\hline 4. & $\begin{array}{l}\text { Analyzing the concept of } \\
\text { compounds in kawa beverage and } \\
\text { their application in everyday life. }\end{array}$ & $\begin{array}{l}\text { Coffee leaves contain many antioxidants, as well as } \\
\text { anti-inflammatory substances. Coffee leaves have } \\
\text { efficacy as a central nervous system stimulant, } \\
\text { because in dry coffee leaves there is } 0.17 \% \text { caffeine. } \\
\text { Due to the low caffeine content, it does not give side } \\
\text { effects to health. }\end{array}$ \\
\hline 5. & $\begin{array}{l}\text { Analyzing varian flavors in the } \\
\text { processing of kawa beverage }\end{array}$ & $\begin{array}{l}\text { Various flavors such as insipidity and bitter taste and } \\
\text { compounds that influence it. }\end{array}$ \\
\hline 6. & $\begin{array}{l}\text { Analyzing the content of the } \\
\text { solution in the kawa beverage }\end{array}$ & $\begin{array}{l}\text { Pure kawa drinks do not use preservatives and } \\
\text { additives such as sugar, milk and others. }\end{array}$ \\
\hline
\end{tabular}

\section{Conclusion}

Based on the results of the study, it was found that the processing of the kawa beverage was carried out traditionally, which was knowledge obtained through generations. The results of the reconstruction of indigenous knowledge into scientific knowledge can be a source of learning for students. Lecturers are expected to be able to correlate between the original knowledge of the community with existing scientific concepts so that learning is expected to be more meaningful and effective. Suggestions for further research are to explore the traditions and culture that exist in Kerinci to be constructed into scientific knowledge that can be used as a learning resource for applied biology.

\section{References}

[1] Ahmad, S., Alam, K., Wariss, H. M., Anjum, S., \& Mukhtar, M.: Ethnobotanical studies of Plant Resources of Cholistan Desert. Int J Sci Res, 3, 1782-8. Pakistan (2014)

[2] Bahar, M., Defrianti, D., \& Fatonah, F.: Fenomena Tradisi Minum Daun Kawo Di Desa Ujung Pasir. Jurnal Titian. Vol. 1, No. 2, pp. 142-155 (2017)

[3] Creswell, J. W.,\&Poth, C. N.: Qualitative Inquiry and Research Design: Choosing Among Five Approache. United States of America. (2018)

[4] Cunningham, A. B.: Applied Ethnobotany: people, wild plant use and conservation. Routledge. (2014)

[5] Hadi, W. P., \& Ahied, M.: Kajian Etnosains Madura dalam Proses Produksi Garam sebagai Media Pembelajaran IPA Terpadu. Jurnal Ilmiah Rekayasa Vol. 10(2), pp. 79-86. (2017)

[6] Hamilton, A., Shengji, P., Kessy, J., Khan, A. A., Lagos-Witte, S., \& Shinwari, Z. K.: The Purposes and Tteaching of Applied Ethnobotany. United Nations Educational, Scientific and Cultural Organization. Unesco. (2003)

[7] Martin, G. J.: Ethnobotany: a methods manual, Routledge (2010)

[8] Meena, M. C., \& Meena, R.: Etnobotanical Studies Of Helicteres Isora-An Important Medicinal Plant. World Journal Of Pharmacy and Pharmaceutical Sciences. India. Volume 1(2), 102-111. (2013)

[9] Meita, F. P., \& Pande, K.: Etnobotani kelapa (Cocos nucifera L.)di wilayah Denpasar dan Badung. Jurnal Simbiosis I. Volume 1(2), 102-111. (2013)

[10] Rasyid, R., Sanjaya, W. F., \& Zulharmita, Z.: Penetapan Kadar Kofein Daun Kopi Kawa (Coffea Robusta, Lind). Jurnal Farmasi Higea, Vol. 5, No. 2. (2013)

[11] Rusdi, M.: Penelitian Desain dan Pengembangan Kependidikan : Konsep, Prosedur dan Sintesis Pengetahuan Baru. PT Raja Grafindo Persada, Depok (2018) 
[12] Sudarmin, S., \& Asyhar, R.: Transformasi Pengetahuan Sains Tradisional menjadi Sains Ilmiah dalam Proses Produksi Jamu Tradisional. Edu-Sains, Volume 1 (1). (2012) 